\title{
The internal audit and corruption: a logic on its own or the circumvention of prevailing logics?
}

\section{A auditoria interna e corrupção: uma lógica por si só ou uma forma de contornar lógicas predominantes?}

\author{
Anderson Luiz Souza ${ }^{1}$, Arnaldo Luiz Ryngelblum ${ }^{2}$ e Celso Augusto Rimoli ${ }^{3}$
}

\footnotetext{
${ }^{1}$ Universidade Paulista, Brasil, Mestrado em Administração, e-mail: luizsoz@hotmail.com

${ }^{2}$ Universidade Paulista, Brasil, Mestrado em Administração, e-mail: arnaldoryn@gmail.com

${ }^{3}$ Universidade Paulista, Brasil, Mestrado em Administração, e-mail: celso.rimoli@gmail.com
}

Recebido em: 28/03/2019 - Revisado em: 15/04/2019 - Aprovado em: 07/05/2019 - Disponível em: 01/07/2019

\begin{abstract}
Despite the establishment of specific norms to deter corruption, it continues to be a challenge for both public agencies and private organizations. In this context, this paper sought to understand how control bodies - among which stands the Internal Audit (IA) - are circumvented, or whether corruption constitutes a logic on its own, with its practices and values. The multiple logic concepts assume that context participants follow at each situation a prescription set defined by a specific logic. Thus, they have to somehow explain their noncompliance with the practices and norms of the logic not being followed. A research was conducted with internal and external audits, and Brazilian control agencies in the financial field to examine the models that analyze this behavior. The results suggest that market logic, reflected in the organization's prioritization of economic performance, tends to prevail in various situations over public logic. This article sheds light on how financial organizations make use of institutional strategies to handle the conflict and maintain their legitimacy in relation to the public logic, by circumventing its prescriptions, which many times lead them to practice corrupt acts.
\end{abstract}

Keywords: Logics, Strategy, Corruptions.

\section{Resumo}

Apesar do estabelecimento de normas específicas para impedir a corrupção, a corrupção por si só continua a ser um desafio tanto para os órgãos públicos quanto para as organizações privadas. Nesse contexto, o trabalho buscou compreender como os órgãos de controle - dos quais se destaca a Auditoria Interna (IA) - lidam com a corrupção, suas práticas e valores. Conceitualmente, os participantes em um contexto imbuído por corrupção tendem a enfrentar dilemas de uma lógica peculiar, que os conduzem a um conjunto específico 
de prescrições, atitudes e pensamentos. Assim, explicações surgem quando determinado comportamento não é observado. Foi realizada uma pesquisa com auditorias internas, externas e agências de controle brasileiras na área financeira, com o intuito de examinar os modelos que justifiquem as lógicas adotadas em prescrições, atitudes e pensamentos. Os resultados sugerem que a lógica de mercado, refletida na priorização do desempenho econômico pela organização, tende a prevalecer em várias situações sobre a lógica pública. Para isso, este artigo esclarece como as organizações financeiras fazem uso de estratégias institucionais para lidar com o conflito de lógicas, mantendo a legitimidade frente à lógica pública, contornando suas prescrições, que muitas vezes, as levam a praticar atos corruptos.

Palavras Chaves: Lógicas, Estratégia, Corrupção.

\section{Introduction}

Organizations of all kinds, private and public, operating in any industry, and in any country, are subject to corruption. Indeed, corruption is characteristic of the very existence of economic activity (Dimant, 2016).

Wells (2007) identifies different types of corruption: (1) bribery, featured primarily as paying values and rendering favors to someone because of hierarchical position (p.240); (2) unwarranted or illegal gratuities, which may influence business decisions, as in a bidding process (p.252); (3) extortion, a type of corruption characterized by the act of threatening someone (p.252); and, finally, (4) conflicts of interest that may carry hidden motivations, where corruption remains unrevealed in buying or selling schemes (p.253).

This classification suggests that corruption is a topic of concern that draws the attention of professionals directly involved in preventing and combating its practice, acting either as advisors to top management or as inspectors of middle management in organizations. According to the Institute of Internal Auditors [IIA] (2015), various organizations and groups are interested in the work of the internal audit (IA). "Internal Audit has become an important element in the assurance environment of many organisations and a valuable tool and contributor to managing risk more effectively." (IIA-Australia, 2014). And the IA, together with the External Audit (EA) have the obligation to report their findings to the Board of Directors, satisfying the periodicity previously defined by each organization and regulatory bodies that regulate every industry.

It is the function and responsibility of IA teams to produce minutes, policies, reports and counselling able to confirm the misdeeds related to objective (monetary values) and subjective (image) losses related to business processes, the conduct of employees, and third parties. It is thus expected that the performance of the IA meet the expectations of the organizations they belong to, as well as those of the market. Different procedures make up the activities of the IA: in addition to evaluating the management of specific business risks, many audits currently carry out activities related to the requirements of the Sarbanes-Oxley Act, which aims to ensure the creation of audit mechanisms and security, so as to mitigate business risks, prevent fraud or ensure that there are ways to identify them when they occur. This does not guarantee but enhances transparency in business management, which may include, in addition to assessments of the design and implementation of internal controls over financial reporting, advisory support to the areas responsible for controls in drawing 
up action plans for solving gaps between the organization structure and its business practice (Lelis \& Mario, 2009).

The Brazilian Anti-Corruption Law (12,846/13, August 1, 2013), which was introduced by the Federal Government and is operated by the Ministry of Transparency, Supervision and Control (MTSC) imposes administrative and civil penalties on acts of corruption against the public administration (Brazil, 2015). The application of similar instruments to the financial market is encouraged by the Brazilian Corporate Governance Institute (IBCG), with the use of a corporate governance system "[...] by which companies and other organizations are managed, monitored and encouraged, which involves (supervising) the relationships between partners, boards of directors, executive officers, supervisory and control bodies, and other stakeholders [...]" (IBGC, 2016). It follows that anti-corruption norms must be included in manuals on work processes and conduct of organization's employees (Itaú, 2015; Santander, 2015).

As can be noticed, there is no shortage of tools for organizations and public authorities to identify and counteract the harms caused by corruption. However, although the duties and responsibilities are outlined with the establishment of specific controls, public and private management misconducts have increased in recent years. In an empirical situation it is considered possible for an organization to do the following: (1) bribe a public agent and (2) vehemently deny what happened, when the authorities take notice of the fact. Recently, Brazilian companies JBS and BR Foods have resorted to such maneuvers to evade the allegations of corruption and questionings on the quality of their products.

Initiatives to curb the advance of corruption have not been successful, resulting in significant financial and credibility losses to organizations and to the financial market. One of these situations occurred when Petrobras, the Brazilian state-owned petrol company, previously known for its technical and economic soundness, was exposed to losses of over $\mathrm{R} \$ 6$ billion (around $\mathrm{U} \$ 2$ billion) due to corruption. Petrobras was unable to mitigate its problems and one of the reasons given was that internal audits were insufficient and unspecific, and therefore unable to identify the phenomenon. The fact that audit reports were not demanded by the company's Board of Directors makes the situation even worse, as it is known that any department in an organization is able to request specific audits. (Petrobras, 2015).

Academic studies on corruption present distinct perspectives about the issue. For example, corruption is sometimes related to the misconducts of individuals (Ashforth, Gioia, Robinson \& Trevino, 2008), related to the deflection of organizational values, and market values (Lanyon \& Goodstein, 2004), and to the economic interests of professionals (Toffler \& Reingold, 2004).

The institutional theory concern is whether corrupt practices can be considered a refusal or evasion to comply with laws and rules, or a logic on its own (Friedland \& Alford, 1991; Thornton \& Ocasio, 2004). In the first case, when actors avoid complying with legislation, the assumption is that actors follow a behavioral pattern in which corruption involves practices that escape some of the indications of the prevailing logics, or, in the second case, actors design and implement corrupt practices, which are accepted by a significant segment of the institutional context, aside from other segments.

Institutional studies consider that organizations in a field participate in the definition of accepted practices and rules about how they should operate, which is a matter of 
constant discussion and redefinition (Thornton and Ocasio, 1999). They understand that not every organization is happy with its respective arrangements, but while most follow the prescriptions established, others search to evade them using different strategies (Oliver, 1991). In this context, in the proposition that considers corruption as evasion of prevailing logics, the paper seeks to understand how control bodies - especially the IA - are circumvented, confronted or manipulated, allowing corruption to spread. However, when corruption is examined as a logic on its own, the proposition implied is that context actors are capable of enforcing the corrupt logic's prescriptions, and compete with other logics for context acceptance.

In order to respond these issues, the paper is organized as follows: after this introduction, the concepts of logic multiplicity and organizational strategies to avoid complying with rules and norms are discussed in the literature review. The methodology and the results section follow, and the paper ends with a conclusion highlighting its contributions and limitations.

\section{Literature Review}

This section, reviews society's central logics, how to recognize them, and the implications of their multiple bearing on actors. As a consequence of the conflicts caused by the presence of multiple logics, the study reviews some of the alternatives organizational actors may resort to when they wish to avoid certain institutional prescriptions.

\subsection{Institutional Logics}

Thornton and Ocasio $(1999,804)$ state that institutions are the result of logics formed by the constant interaction of objective and subjective elements: "[...] socially constructed historical patterns, from which individuals: (a) organize time and space; (b) reproduce their material substance; and (c) provide meaning to their social reality".

Friedland and Alford (1991, 232) described society as an "interinstitutional system" composed of the following central institutions in Western society: capitalist market; bureaucratic state; democracy; nuclear family; and the Christian religion. According to the authors, these institutions "shape individual preferences and organizational interests as well as the repertoire of behaviors by which they may attain them." The authors also emphasize the fact that because society is an interinstitutional system, the distinct practices and beliefs originated in each central institution may generate contradictions and conflicts in a context.

Additionally, Thornton and Ocasio (2008) have defined institutional logics as "socially constructed, historical patterns of material practices, assumptions, values, beliefs, and rules by which individuals produce and reproduce their material subsistence, organize time and space, and provide meaning to their social reality".

Greenwood, Raynard, Kodeih, Micelotta and Lounsbury (2011), while mentioning the multiplicity of logics in an institutional field, highlight the conflict experienced by the actors, who must attend to indications of different logics, which may have contradictory demands and constraints on the actors. Under these circumstances it is possible to say that organizations face an institutional complexity that incites them to look for ways to respond appropriately to those demands they are unwilling or unable to attend. Demands 
originating from different logics may stand in contradiction, and accordingly organizations must prioritize a specific one over others under given circumstances. This is the case when a bank has to consider public laws and rules and, at the same time, its own profitability, and also perhaps issues of corporate responsibility that conflict among themselves

Other studies point to situations in which a prevailing logic imposes a subsidiary role to the others (Thornton \& Ocasio, 1999, Ocasio \& Radoynovska, 2016). In these cases, actors would have no doubt which logic to follow. In studies focusing logics hybridization (Battilana \& Dourado, 2010; Haigh \& Hoffman, 2014; Pache \& Santos, 2013), actors would respond to the resulting logic. Other studies, in turn, indicate a context in which different logics coexist ( Meyer \& Hölerer, 2016), revealing a complex context (Misangyi, 2016; Raynard, 2016). The analysis that uses the coexistence perspective has to consider that, under such circumstances; actors need to balance their choices. While attending practices and values of one of the logics, they would also need to show that what they are practicing is legitimate according to the other logics' orientations. However, this is not always possible and, in such a condition, actors would adopt subterfuges to make their activities seem legitimate or they would try to modify the standards of a logic they cannot meet (Friedland \& Alford, 1991).

This paper proposes that among the main logics present in an organizational field are the following: market logic, public logic, and corruption logic, in case this latter may be considered a socially constructed historical pattern; otherwise, it should be considered, a means to evade other logics determinations (Thornton \& Ocasio, 1999).

A market logic involves the search for profits, lowering costs, market share acquisition, investor decisions, among other activities. It can be identified also in what Rossoni and Machado (2010, p.185) called "compensation system for executives and advisors", which consists of practices aligned with the decisions of directors and executives in pursuit of objectives leading to the maximization of results for the company. At the same time, it fosters high remuneration to the top management. According to Roe (2008), much of the executives' and directors' compensation is composed of bonds represented by stock shares. These top management compensations are employed to encourage market performance. It is also advantageous for shareholders who can buy and sell shares in the stock market, and to employees who can have greater participation in the profits, given the valuation of the company.

The government is involved with public logic but also other context participants, which concerns the society's wellbeing, involving the good functioning of the market, and that of its citizens. Some of the activities undertaken to attain this purpose are to regulate the practices and rules with which organizations must comply, such as society's normalization of professions and corporate governance. For example, the study of corporate governance practices emphasizes the process of institutionalization of managerial practices, pointing to the efficiency of control systems (Rossoni et al., 2010), through which an organization gains legitimacy (Suchman, 1995; Navis \& Glynn, 2011). The public logic involves state practices, represented by the rationalization and regulation of social activities through legal and bureaucratic orders and oriented to the defense of rights, citizenship and social welfare (Costa et al., 2013, p.105).

Lastly, corruption according to Ashforth et al. (2008) is motivated by the human disposition to endorse distorted notions about ethics and moral. Practices can also reach organizations through exogenous stimuli through the pre-disposition of individuals, 
according to Lanyon and Goodstein (2004), setting what Getz (2006) calls deviations rooted in micro, meso and macrosocial levels. The institutional perspective, however, does not limit its analysis to individual actions. It analyzes organizational and individual actions to question whether practices related to bribery, extortion, undue gratification and conflict of interests (Wells, 2007) have already established a socially constructed behavior pattern which participants understand and confirm. For this to happen, field participants, or at least a significant group of them, would have either to agree with these practices or be coerced to accept them.

Corruption can also be thought as a set of activities that are not approved by large segments of society, but its widespread practice suggests that certain social actors obtain undue advantages from it and seek to obtain legitimacy using specific strategic practices not to be labeled as corrupt actors (Pache \& Santos, 2010a). The idea is to avoid sanctions by other field participants, but this can also be attained when these participants are unaware of the misdeeds or are unable to perceive them. The next section examines how organizations maintain their legitimacy in relation to a logic they have not chosen to privilege at a certain moment or event.

\subsection{Logics determining strategies}

Thornton and Ocasio (2008), among others, propose that logics are the result of a collective construction involving context actors' practices, their understandings of the reasons for these practices, and their symbols. Therefore, considering that strategies are organizational practices, they must be understood as a means by which actors try to influence the context's definition of a logic and also a way to attain the organization's objectives even when it faces constraints.

The concomitant consideration of various logics (Friedland \& Alford, 1991; Thornton \& Ocasio, 2008; Greenwood et al., 2011; Ocasio \& Radoynovska, 2016; Raynard, 2016), in order to achieve legitimacy (Suchman, 1995; Navis \& Glynn, 2011), channels field actors to adopt strategies to evade a given logic's prescriptions, while attending to another logic that is guiding the actor's practices at some point. Different authors have examined this possibility. Meyer and Rowan (1977) called ceremonialism the adoption of technical solutions while claiming to give attention to institutional prescriptions. Greenwood, Raynard, Kodeih, Micelotta, and Lounsbury (2011) considered the coexistence of multiple logics in a context and described that their competition triggered conflict between them.

Oliver (1991, p. 151) analyzed institutional strategies in relation to a dominant logic, whether an actor complied with institutional prescriptions or not. Oliver's taxonomy (1991, p.151) is useful to investigate which organizational strategies are mobilized in corrupt practices, if in fact they are means of evading institutional prescriptions. Among the possible strategies from the taxonomy, the following are capable of explaining circumvention practices: when an actor (i) avoids the orientations, (iv) challenges the prescriptions, (v) manipulates the orientations. The choice of Oliver's taxonomy lies in its potential, since it seems reasonable to imagine action alternatives in relation to institutional constraints (Scott, 1991; Powell, 1991). 
Table 1: Strategies to respond to institutional logics

\begin{tabular}{|l|l|}
\hline Strategies & Organizational Action \\
\hline \multirow{4}{*}{ Circumvention } & Disguise non-conformity \\
\cline { 2 - 2 } & Make believe a fictitious conformity \\
\cline { 2 - 2 } & Weaken institutional ties \\
\cline { 2 - 2 } Confrontation & Change organizational goals, activities, domains to eliminate non-conformity \\
\cline { 2 - 2 } & Ignore explicit norms \\
\cline { 2 - 2 } & Contest indications and requirements \\
\hline \multirow{3}{*}{ Manipulation } & Confront institutional pressure in favor of an organization's objectives \\
\cline { 2 - 2 } & Slightly alter rules and practices \\
\hline
\end{tabular}

Source: Adapted from Oliver (1991, p.152)

Table 1 depicts behaviors of organizations that make use of circumvention, confrontation and manipulation strategies to avoid complying with institutional prescriptions (Scott, 1991; Oliver, 1991; Pache \& Santos, 2010b). Organizations may adopt these strategies when they prioritize the fulfillment of a logic that conflicts with others in the field. Financial organizations have to comply with conditions prescribed by law, while at the same time they would like to take advantage of market opportunities that may be restricted. This is the case of public and market practices, encouraging them sometimes to not comply with the rules, especially when sanctions are hardly applied (Toffler \& Reingold, 2004; Lounsbury, 2007).

Thus, as a synthesis of the previous discussion, we propose to examine if in order to achieve legitimacy when facing conflicting logics in a field, organizations make use of strategies such as circumvention, confrontation and manipulation that may result in corrupt practices. We also propose to verify whether corruption can be considered a logic on its own, due to its particular practices, structures, and values. The following methodology section describes the investigation carried out to examine the corruption phenomenon.

\section{Methodology}

This research is descriptive and explanatory, as it aims to clarify the different representations of a case and the reasons that constitute it. We used case study as a research strategy as itallows the understanding of complex social phenomena and also the investigation of various levels of analysis within it (Yin, 2010, p.29; Eisenhardt, 1989, p. 534). It should be highlighted that in the interviews corruption was approached through the presentation of examples extracted from cases reported in communication vehicles (websites, newspapers and magazines). This caution was taken in order to avoid any embarrassment or the use of confidential inside information on the part of the respondents. We assumed that while commenting on actions of other companies involving similar illicit acts the respondents would reflect the same practices and perceptions as those of the focused company.

\subsection{Research Object}

We make use of the notions of field, organizations in an industry and organizations "supporting, policing or setting policy toward the industry " (DiMaggio, 1991, p. 267). In this case, a financial organization, here called Gamma Financial Company, was investigated, due 
to the diversity of operations it performs and its representativeness in the financial Brazilian sector. Its operations encompass government, authorities and prominent financial market investors. Operating for more than 40 years in the credit market, agribusiness and high risk investments in capital market segments, Gamma guaranteed the adoption of strategies based on three main stakes: good knowledge of the needs of each client; agility of operation; and by strengthening management structures. On its official website, Gamma emphasizes the importance of its decision-making process and claims to have a code of ethics aligned with its internal culture. Moreover, Gamma affirms that its auditors are institutionally involved in investigating illicit activities and management processes. In addition to that, its top management sponsors a culture of control and transparency in the relationship with investors and employees, regardless of hierarchical position or influence. The other actors considered in the field included an external auditing firm, and governmental bureaus, such as the Central Bank, responsible for setting policies regarding ethical conduct, and MTSC, the ministry that monitors wrongdoings in business and public administration.

The respondents interviewed included (I) Gamma's external auditor, a key element in the verification of corruption cases, (II) the company's general manager, and (III) the internal audit assistant, professionals responsible for the verification and reporting of ethical and operational deviations to the Board of Directors. We also interviewed a member of (IV) the Audit Committee, reporting to the Board of Directors that is responsible for the adherence to government controls and oversight bodies' rules. In relation to the regulatory and inspection agencies, we were only able to interview a representative of the (V) MTSC control agency, a federal bureau responsible for combating corruption in the country, and had great difficulty in accessing other organizations, such as the Central Bank.

The triangulation of the information was possible contrasting the different points of view of the respondents. The points of view represented by different field organizations, as well as, the departments responsible for monitoring corruption in the financial organization.

\subsection{Data Collection}

Data collection was conducted from in-depth interviews and secondary sources (Yin, 2010, Eisenhardt, 1989, p 534). In order to operationalize the interviews we developed and tested scripts addressing the knowledge of the respondents on the issue of corruption and its implications, controls and laws. The perspective of analysis regarded the relation between multiple logics and the resulting strategies to manage the pressures posed by the organizational field. As informed before, the script questions brought examples of corruption portrayed by the media, an indirect way of approaching the subject which avoids exposing the particularities experienced by interviewees related to the organization researched.

Interviewees were asked about Petrobrás (Estado de São Paulo, 2017) and Bradesco $(R 7,2017)$ corruption cases. In addition to the interviews with the financial organization respondents, the EA, and the MTSC control agency, secondary data sources also contributed importantly; these were accessed virtually, through the Electronic System of the Citizen Information Service (e-SIC). These secondary data referred to the agency's reports and audits, responsible for the application of the Brazilian Anti-corruption law 12.846/13. These reports came from the MTSC and the Union's Comptroller General. The analysis of interviews and documents collected was essential to achieve the study's objectives, since they promoted the triangulation necessary to validate the data sources used by the researchers (Yin, 2010). 


\subsection{Data Analysis}

Among the methods assigned to the purpose of analyzing the information collected, the use of the combination of patterns is highlighted. This technique provides a good example of a comparison between concepts and constructs suggested by theory, to what is interpreted in the interviewees' speech (Yin, 2010, p. 162). In addition to using the combination of patterns to establish validity, organization and classification of meanings, thematic analysis was used which, according to Bardin (2007), is a suitable technique to bring the researcher's attention to what matters. Thematic analysis as a method is divided into three phases: (1) Pre-analysis, initiated with the activity known as "floating reading", in which an initial view of the material under analysis is sought. (2) Exploration of the material, started with the decoding of the information, associating it to the meanings and the subject under study. (3) Treatment and interpretation of findings, which is initiated by proposing inferences towards the objectives, or relating to other unexpected discoveries. (Bardin, 2007, p.101).

The combination of patterns and thematic analysis enabled the codification of the transcribed responses, associating them with the categories previously proposed in the literature review: market logic, public logic, and corruption logic or evasion strategy (Friedland \& Alford, 1991; Thornton; Ocasio, 2008). The strategies considered were: circumvention, confrontation and manipulation (Oliver, 1991). In the following sections, these methodological considerations are put into practice by analyzing and debating research findings.

\section{FINDINGS}

In this section, the paper brings the interviewees' answers enriched by data and information collected from secondary sources according to the different logics mentioned and the strategies resulting from them.

\subsection{Market Logic}

Elements from the market logic are present in the discourse of most respondents because of the importance given to profit, cost reduction and the option for conservative or risky investments. These items are frequently associated with strategic objectives and the alternatives chosen by the Gamma organization to achieve them. According to the interviewees' assessments, a financial organization, in order to attain its goals, may opt to carry out corrupt actions or not. The Audit Committee Advisor, for example, suggests that the choices are scrutinized by each financial organization's board. "I believe there is no flaw in internal controls, including those aimed at fighting corruption, but what is still there is the appetite for risk from those who like to bet high. When the thing is top-down, right or wrong things may happen."

This speech alludes to the accusation of corruption involving major Brazilian banks, such as Bradesco $(R 7,2017)$. As an advisor and member of the audit committee of a financial organization, the interviewee's remarks seem to reveal a strategic point of view, aimed at profits and at protecting organizational status and image at all costs. Thus, his comments 
suggest that the fight against corruption may be subordinate to the decisions of the board of directors, since "... advisors are concerned with the problems and the risks."

Thus, even if the IA is aware of possible irregularities, it will be held hostage by its hierarchical subordination. The dominance of market logic over governance procedures, for example, values corrupt actions and suggests strategies to avoid potential conflicts of interest.

\subsection{Public logic}

Elements of the public logic in the financial field can be identified in the speech of the External Auditor when he makes observations about the effects of different investigations (Galileu, 2017) conducted by the Public Ministry (federal independent prosecutor's office). "[...] Brazilian companies and audits are concerned with ethical and legal issues. The main reason is [sic] the investigative operations that have lately gained great repercussion, such as Lava Jato, Zelottes, Mensalão, Greenfield".

With his broad experience, the interviewee, who also audits other organizations, was led to suggest that the investigative operations imposed by the public office bring concern to organizations, due to the controls meant to guarantee transparency in the way these organizations conduct their businesses.

The Internal Audit Manager, another interviewee, seems to welcome the idea that the public logic is attuned with the pressures of the field, leading banks, finance companies and credit cooperatives to adopt new structures responsible for encouraging the prevention illicit acts. However, according to his evaluation, this movement towards standardization of the sector's practices and structures is not a peaceful change process, as it is the reflection of the coercion by regulatory and supervisory agencies, such as CGU and Brazil's Central Bank-BACEN. Both institutions could elicit obedience from some organizations and arouse resistance to comply from others. Obedience, since the regulatory and supervisory bodies have the power to question how an organization conducts its business, even leading it to shut down if legal norms are not met. The changes imposed by the pressures from these agencies may cause organizations to individually reassess their guidelines in terms of what is more relevant in a given requirement, involving their compliance or not with the rules. This discussion brings light into why an organization can be supportive for the fight against corruption and, in the next minute, chooses to practice it.

The relevance of the IA becomes clear in this context. According to the opinion of the Audit Committee Advisor, IA represents an important control and advisory tool for top management. Its relevance to business is associated with its operational value, attributed to the auditor's function. Also, its institutional relevance is attributed to the differential it produces as it is able to act strategically in the prevention of risks, among which that of corruption is included. This is a condition that in practice is translated into following the rules, without forgetting the peculiarities and needs of the business. The Audit Committee Advisor still suggests that the Board of Directors of organizations should approach their IAs, since enhancing control policies does not alienate the organization from its strategic objectives. 


\subsection{Corruption Logic or Strategic Action?}

Elements of corrupt practices may be perceived in the IA Assistant's statement, which provides an example of how it is justified: "[...] the client is the value, so one cannot just close his account because one thinks he is involved in corruption. One needs a legal definition of it, and afterwards it is worth evaluating the loss that this operation can bring to the bank's profitability if maintained".

This interviewee's speech indicates that the decision between maintaining the relationship with the client or terminating it is strategic and may vary from case to case, regardless whether or not it is mediated by corruption. From another angle, market logic seems to orient the assistant's reasoning, which suggests a prevalence of this logic over a public one.

The member from the External Audit interviewed complements the previous interviewee's reasoning, who argues that communiqués and training on ethics and transparency in organizations can mask elements of corrupt practices. According to him, "[...] governance and compliance training, for example, are underlined when problems with managers' lack of honesty begin to appear in organizations, but quickly lose space when it is possible to sweep the wrongdoings under the rug".

In this way, dealing with corruption requires the organization to adequately estimate the risks involved in its relationship with clients that invest large amounts of money coming from suspect sources. At the same time, one has to consider the impact that terminating relationships with these clients may generate in the compensation of executives and advisors.

While explaining the bank business practices, the interviewee inadvertently exposed the choice of winding paths that place corrupt values above notions of ethics and transparency in financial operations.

Another indicator of this mentality is the timid response from financial organizations to the Integrity Program, instituted and monitored by the MTSC (CGU, 2016). According to this agency, companies and banks seem to be reluctant to change values, practices, and structures in order to fight corruption, which may raise a proposition about the presence of corruption logic. The recurrent scandals are examples that shed light on the disregard for laws and practices of governance. Efforts to seek ethics and transparency in business relations between public and private organizations have gained room for discussion in Brazil, but according to the assessment of the MTSC, they are still insufficient (CGU, 2016).

This study did not identify practices related to bribery, extortion, undue gratification, or conflict of interests (Wells, 2007) to categorize them as corruption. However, the previous admissions indicate leniency towards practices that favor economic gains. It is not possible based on these evidences to recognize such lenient admissions as corrupt practices and thus a logic by itself, once that it cannot be classified as a constructed pattern of behavior and understanding by the field's actors, because of its sporadic nature and participation. It is not possible also to perceive an exclusive human disposition to produce corrupt acts (Ashforth 
et al., 2008; Lanyon and Goodstein (2004), because the testimonies and documents point to corporate assessments and decisions.

\subsection{Logics Influencing Strategies}

The previous sections have shown the influence of market logic strongly present in the executives' minds, but also a conscience about the need to respond to a public logic. Executives recognize the determinations of governmental agencies regulations, having to do with corruption control in their daily activities, and at the same time they have to perform economically, which in certain situations may expose them to bribery, undue advantages, or other situations that characterize corrupt actions.

Actors in an organizational field are normally submitted to multiple logics at the same time and they tend to prioritize one of them according to the event they are submitted to, while trying to avoid being sanctioned by another logic that has been dropped. Thus, abiding by market principles may put an actor under suspicion when being assessed by a public logic.

The External Auditor's remarks about the firms' concerns due to the operations of the Public Ministry, in addition to the control measures to bring transparency, suggest that organizations now seem to be well aware of the dangers of doing something illicit. However, organizations seem to maintain corrupt practices, despite their previous knowledge of what the practices implied under the scrutiny of the public logic. The IA manager clearly admitted the possibility of non-obedience by some organizations. Similarly, the Audit Committee Advisor made it clear that controls will work up to a certain point. When the appetite for profit becomes high, decisions may be in the direction of doing whatever is necessary, in his words.

The declarations of executives that it is important to profit irrespectively of what corrupt practices may imply, suggests that these practices stand in opposition to the public logic, which would characterize a confrontation strategy. However, these actions are manifested only in a few occasions and organizations do not publicize them, expecting not to be discovered. In this case, it may be considered an instance of a circumvention strategy.

Considering the taxonomy depicted in Table 1, that shows strategies that respond to the pressures of institutional logics, it looks like the pressures from both public and market logics may lead an organization to avoid the public logic by disguising conformity, or weakening institutional ties (e.g., influence trafficking). It could also manipulate regulatory requirements (e.g., unclear dividend policy for major shareholders); or even confront requirements (e.g., opening a new account with suspicious funds).

To avoid being sanctioned by a logic not primarily attended to, a person or an organization would choose to employ one of the evasion strategies in order to keep legitimacy. In any case, until recently these corrupt practices seemed to be easier to accomplish due to reduced sanctioning by the supervisory agencies and little awareness by the other field actors, such as the clients of financial organizations, the media, etc. 


\section{Conclusion}

This study asserted that even though organizations face regulatory regimes and usually keep internal and external controls schemes over corrupt practices, these practices keep being unveiled, investigated, and sued. Control schemes may be internal departments, such as the IA, as well as external sources, such as EA, that double check the practices and documents of organizations, both being instructed and supervised by government and financial agencies. The increase in cases of corruption in Brazil is due to the increase in the rhythm of such investigations by the Public Ministry, created in 1988.

The literature on corruption pointed that its occurrence is due both to individual misconduct and to environmental influence. The application of institutional concepts, on the other hand, allowed the formulation of a proposition based on the notion of multiple conflicting logics in a field, that to achieve legitimacy, organizations may make use of strategies such as circumvention, confrontation and manipulation, to evade complying with one logic while favoring another. It means that when distinct logics coexist in the same organizational field and actors are called to follow one of them, while having to keep up their legitimacy in relation to the others, they tend to use these strategies in order to avoid complying with established rules. To achieve that, actors make use of strategic practices to favor one of the logics in detriment of others. We interviewed executives of Gamma Financial Company, external suppliers, and a professional from a regulatory agency to explore their understanding about the functioning of internal and external controls. Their answers, based on questions about corrupt actions provided by secondary sources, mainly from the media, were convergent, confirming the proposition previously presented.

As limitations of the present work, its conclusions are restricted to the data obtained through secondary sources (newspapers, websites, and magazines) and the opinion of the interviewees, supported by the reality that they experience in the financial organization where the research was conducted. The opinions of interviewees about corruption were based on their perception of facts portrayed by the mainstream media and experiences in the organization. The possibility elicited that corruption might be considered a logic by itself could not be assessed, because the delicate subject did not allow neither the admission by the interviewees of corrupt acts such as bribery, extortion, and others, nor were there enough testimonies to suggest such a trend.

Contextual actors such as the Central Bank of Brazil (BACEN); the Financial Activities Control Council (COAF) and the Brazilian Securities and Exchange Commission (CVM), when requested, declined to participate in the interviews. The reason presented was that offering information from public bodies to attend to a study of private nature would be a discretionary act (at will) of the public administrator. In this case, since there was no official obligation (LAI - Information Access Law) or the interest of public bodies to participate, the invitations were refused.

Another important aspect is the fact that the research method used was the single case study research and so the results cannot be generalized to other contexts (Yin, 2010). This is so because, even fulfilling its role of finding answers this study brings the need of replications and further questionings. For future research, we suggest the use of other methodological approaches, such as multiple case study and quantitative modes of analysis, which require sample amplification and the use of statistical metrics. In addition, it is of 
interest to replicate the research to other types of organizations, for we believe that this topic has great potential to contribute to the current business, political and social reality.

\section{References}

ASHFORTH, Blake E. et al. Re-viewing organizational corruption. Academy of Management review, v. 33, n. 3, p. 670-684, 2008.

BARDIN, Laurence. Análise de conteúdo. $3^{\text {a }}$. Lisboa: Edições, v. 70, 2007.

BATTILANA, Julie; DORADO, Silvia. Building sustainable hybrid organizations: The case of commercial microfinance organizations. Academy of management Journal, v. 53, n. 6, p. 1419-1440, 2010.

CGU -Controladoria Geral da União (2016). Retrieved from: http://www.cgu.gov.br/noticias/2016/02/ cgu-avalia-politicas-de-integridade-de-quatro-estatais

COSTA, Mayla Cristina; GUARIDO FILHO, Edson Ronaldo; GONÇALVES, Sandro Aparecido. Lógicas institucionais e formação da governança de recursos hídricos: análise do caso brasileiro. Revista Gestão Organizacional, v. 6, n. 4, 2013.

DIMAGGIO, P. J. (1991). Constructing an organizational field as a professional project: US art museums. 1920.

DIMANT, Eugen; SCHULTE, Thorben. The nature of corruption: An interdisciplinary perspective. German LJ, v. 17, p. 53, 2016.

EISENHARDT, Kathleen M. Building theories from case study research. Academy of management review, v. 14, n. 4, p. 532-550, 1989.

ESTADO DE SÃO PAULO, Curituba, 20 out 2017. Retrieved from: http://politica.estadao.com.br/ blogs/fausto-macedo/procuradoria-aponta-o-custo-da-corrupcao-na-petrobras/

FRIEDLAND, Roger; ALFORD, Robert R. Bringing society back in: Symbols, practices and institutional contradictions. 1991.

GALILEU, Curitiba, 01 jun. 2017. Retrieved from: http://revistagalileu.globo.com/Sociedade/ noticia/2017/06/os-nomes-mais-criativos-de-operacoes-da-policia-federal.html

GETZ, Kathleen A. The effectiveness of global prohibition regimes: Corruption and the antibribery convention. Business \& society, v. 45, n. 3, p. 254-281, 2006.

GREENWOOD, Royston et al. Institutional complexity and organizational responses. Academy of Management annals, v. 5, n. 1, p. 317-371, 2011. 
HAIGH, Nardia; HOFFMAN, Andrew J. The new heretics: Hybrid organizations and the challenges they present to corporate sustainability. Organization \& Environment, v. 27, n. 3, p. 223-241, 2014.

IBGC - Instituto Brasileiro de Governança Corpotativa. Governança corporativa. Retrieved from: http://www.ibgc.org.br/index.php/governanca/governanca-corporativa (2016)

IIA-Institute of Internal Audit. Normas Internacionais para a Prática Profissional de Auditoria Interna (Normas). Retrieved from: http://www.iiabrasil.org.br/ippf.html (2015)

IIA-Institute of Internal Auditors-Australia (2014) Internal Audit: Why it's important. Retrieved from: http://www.iia.org.au/sf_docs/default-source/quality/why-ia-is-important.pdf?sfvrsn=2

Itaú. Política Corporativa de Prevenção à Corrupção. Retrieved from: https://www.itau.com.br/_ arquivosestaticos/RI/pdf/pt/POLITICA_CORPORATIVA_DE_PREVENCAO_A_CORRUPCAO_ PORT.pdf (2015)

LANYON, Richard I.; GOODSTEIN, Leonard D. Validity and reliability of a pre-employment screening test: the counterproductive behavior index (CBI). Journal of Business and Psychology, v. 18, n. 4, p. 533-553, 2004.

Lei $\mathrm{n}^{\circ}$ 12.846/13 de 1 de agosto de 2013. Dispõe sobre a responsabilização administrativa e civil de pessoas jurídicas pela prática de atos contra a administração pública, nacional ou estrangeira, e dá outras providências. Retrieved from: http://www.planalto.gov.br/ccivil_03/_ato2011-2014/2013/lei/ 112846.htm

LELIS, Débora Lage Martins; MARIO, Poueri do Carmo. Auditoria interna com foco em governança, gestão de riscos e Controle interno: análise da auditoria interna de uma empresa do setor energético. In: Congresso USP de Controladoria e Contabilidade, $9^{\circ} .2009$.

LOUNSBURY, Michael. A tale of two cities: Competing logics and practice variation in the professionalizing of mutual funds. Academy of management journal, v. 50, n. 2, p. 289-307, 2007.

MEYER, Renate E.; HÖLLERER, Markus A. Laying a smoke screen: Ambiguity and neutralization as strategic responses to intra-institutional complexity. Strategic Organization, v. 14, n. 4, p. 373-406, 2016.

MEYER, John W.; ROWAN, Brian. Institutionalized organizations: Formal structure as myth and ceremony. American journal of sociology, v. 83, n. 2, p. 340-363, 1977.

MISANGYI, Vilmos F. Institutional complexity and the meaning of loose coupling: Connecting institutional sayings and (not) doings. Strategic Organization, v. 14, n. 4, p. 407-440, 2016.

NAVIS, Chad; GLYNN, Mary Ann. Legitimate distinctiveness and the entrepreneurial identity: Influence on investor judgments of new venture plausibility. Academy of Management Review, v. 36, n. 3, p. 479-499, 2011. 
OCASIO, William; RADOYNOVSKA, Nevena. Strategy and commitments to institutional logics: Organizational heterogeneity in business models and governance. Strategic Organization, v. 14, n. 4, p. 287-309, 2016.

OLIVER, Christine. Strategic responses to institutional processes. Academy of management review, v. 16, n. 1, p. 145-179, 1991.

PACHE, Anne-Claire; SANTOS, Filipe. When worlds collide: The internal dynamics of organizational responses to conflicting institutional demands. Academy of management review, v. 35, n. 3, p. 455476, 2010a.

PACHE, Anne-Claire; SANTOS, Filipe M. Inside the hybrid organization: An organizational level view of responses to conflicting institutional demands. $2010 \mathrm{~b}$.

PACHE, Anne-Claire; SANTOS, Filipe. Embedded in hybrid contexts: How individuals in organizations respond to competing institutional logics. In: Institutional logics in action, part B. Emerald Group Publishing Limited, 2013. p. 3-35.

PETROBRAS. Petróleo Brasileiro S.A. (2015) Fatos e dados. Retrieved from: http://www.petrobras. com.br/fatos-e-dados/divulgamos-nossas-demonstracoes-contabeis-auditadas.htm

POWELL, Walter. Expanding the scope of institutional analysis. The new institutionalism in organizational analysis, Chicago, p. 183-203, 1991.

R7, Brasil, 27 jan. 2017. Retrieved from: https://noticias.r7.com/economia/alvo-da-zelotes-bradescopodera-ser-punido-com-base-na-lei-anticorrupcao-30012017

RAYNARD, Mia. Deconstructing complexity: Configurations of institutional complexity and structural hybridity. Strategic Organization, v. 14, n. 4, p. 310-335, 2016.

ROE, M. J. The institutions of corporate governance. In: Handbook of new institutional economics. Springer Berlin Heidelberg, 371-399, 2008.

ROSSONI, Luciano; MACHADO-DA-SILVA, Clovis. Organizational Institutionalism and Corporate Governance (Institucionalismo Organizacional e Práticas de Governança Corporativa)(Portuguese). 2010.

SANTANDER S/A. Política de Anticorrupção e Suborno. Retrieved from: https://sustentabilidade. santander.com.br/pt/Governanca/PDF/Politica\%20Anticorrupcao\%20vs\%20Port\%20fev-2016.pdf (2015)

SCOTT, W. Richard. Unpacking institutional arrangements. The new institutionalism in organizational analysis, 1991.

SUCHMAN, Mark C. Managing legitimacy: Strategic and institutional approaches. Academy of management review, v. 20, n. 3, p. 571-610, 1995.

THORNTON, Patricia H. Markets from culture: Institutional logics and organizational decisions in higher education publishing. Stanford University Press, 2004. 
THORNTON, Patricia H.; OCASIO, William. Institutional logics and the historical contingency of power in organizations: Executive succession in the higher education publishing industry, 19581990. American journal of Sociology, v. 105, n. 3, p. 801-843, 1999.

THORNTON, Patricia H.; OCASIO, William. Institutional logics. The Sage handbook of organizational institutionalism, v. 840, p. 99-128, 2008.

TOFFLER, Barbara Ley; REINGOLD, Jennifer. Final accounting: Ambition, greed, and the fall of Arthur Andersen. Crown Business, 2004.

WELLS, Joseph T. (Ed.). Fraud casebook: Lessons from the bad side of business. John Wiley \& Sons, 2007.

YIN, R. Estudo de caso: planejamento e métodos Bookman: Porto Alegre. 2010. 